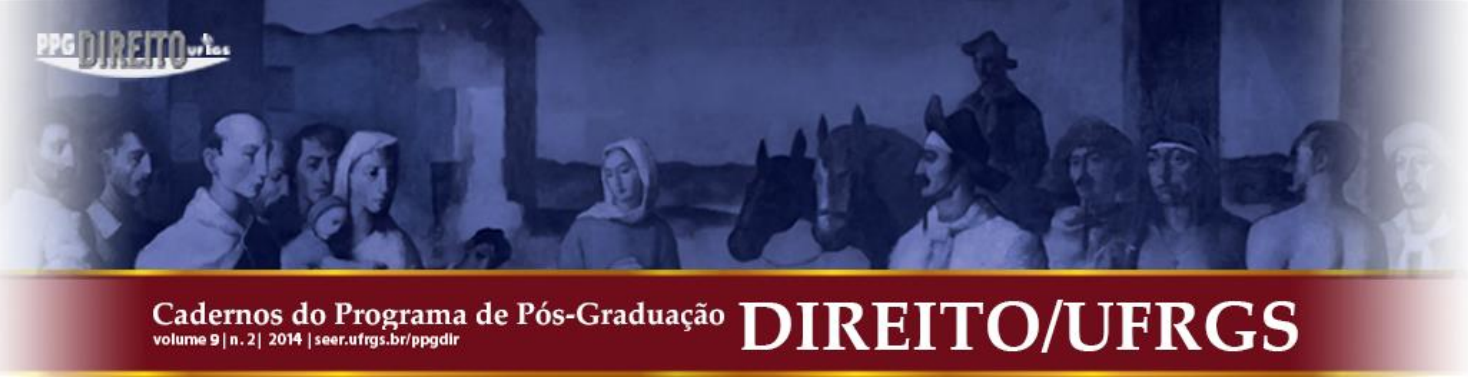

\title{
A TRIBUTAÇÃO DO EXPATRIADO ESTRANGEIRO À LUZ DO DIREITO INTERNACIONAL TRIBUTÁRIO DO BRASIL
}

\author{
THE TAXATION OF FOREIGN EXPATRIATES IN ACCORDANCE WITH BRAZILIAN \\ INTERNATIONAL TAX LAW
}

Ana Carolina Assumpção Stoffel*

\begin{abstract}
RESUMO: É indiscutível que o Direito Internacional Privado vem ganhando cada vez mais destaque dada a sua crescente aplicação no presente cenário mundial, especialmente diante da globalização que promove a incessante interação entre pessoas jurídicas e físicas de diferentes nacionalidades. Como uma das resultantes desse fenômeno, inúmeros profissionais são transferidos de seu país de origem, a fim de fixar residência na localidade em que a empresa para a qual trabalha possui filial, matriz ou subsidiária. Ou seja, a expatriação vem se tornando um acontecimento frequente em empresas multinacionais, e dada a complexidade envolvida no processo de transferência de um funcionário de um país para o outro, a temática precisa ser considerada de diferentes ângulos: jurídico, cultural, político, econômico, entre outros. Nessa direção, o presente trabalho dedica-se a análise das principais questões ligadas à tributação de estrangeiros que se encontram no Brasil, por questões laborais, o que significa apontar para a tributação de rendas e proventos de qualquer natureza, além de abordar critérios de conexão e residência fiscal no Direito Internacional Tributário e, por fim, abordar a relação dos principais vistos com a tributação e a política de equalização fiscal
\end{abstract}

PALAVRAS-CHAVE: Direito Internacional Tributário; Expatriado-estrangeiro; Residência fiscal; Tratados Internacionais Tributários.

SUMÁRIO: Introdução. 1. Definições preliminares: estrangeiro, expatriado e expatriação. 2. A residência fiscal sob a ótica do direito tributário internacional do Brasil. 2.1. Da aplicação do direito internacional privado do Brasil e dos elementos de conexão na seara tributária. 2.2. Residência fiscal de acordo com a legislação brasileira e sua relação com o tipo de visto ostentado pelo expatriado estrangeiro. 2.2.1. Visto temporário com e sem contrato de trabalho. 2.2.2. Visto temporário para assistência técnica e cooperação técnica. 2.2.3. Visto permanente. 3. Tratados internacionais tributários. 4. A. "equidade fiscal": a política de equalização fiscal. Considerações finais. Referências.

\section{INTRODUÇÃO}

Os estudos sobre os impactos da globalização, em distintas sociedades, têm ressaltado, entre outros aspectos, a maior interação promovida entre os países e, de igual modo, a aproximação entre pessoas de diferentes nacionalidades. Em decorrência desse novo panorama, percebe-se, gradativamente, a consolidação do "jusprivatismo internacional" (BASSO, 2009) que se reflete diretamente na seara tributária, conforme será ora explanado.

\footnotetext{
* Especialização em Direito Tributário na Pontifícia Universidade Católica de Minas Gerais e Especialização em Direito Internacional no Centro de Direito Internacional.
}

ABSTRACT: There is no doubt that Private International Law is gaining more and more prominence due to its growing application in that promotes the non-stopping interaction between companies and individuals of different nationalities. As a result of this phenomenon, many professionals are transferred from their country of origin, in they work for has an affiliate, matrix, or subsidiary. I.e., expatriation is a commonplace event in multinational companies and given the country to another, the issue needs to be considered from different angles: legal, cultural, political, economic, etc. Thus, this paper foreigners that are in Brazil for labor issues, which means pointing to approach the criteria of connection and tax residence under the the main types of visa with taxation and the policy of fiscal

KEYWORDS: International Tax Law; Foreigner expatriates; Tax residence; International Tax Trade. at the taxation of their income and earnings of any nature, as well as 


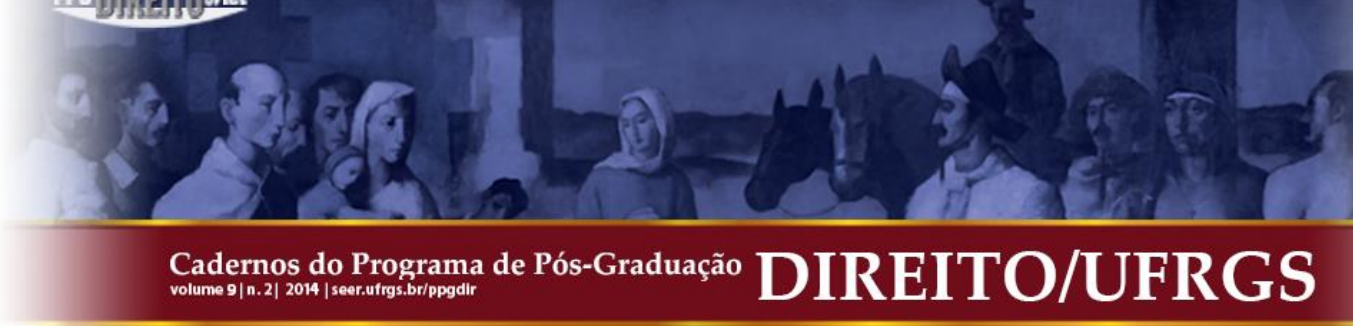

Esse fenômeno já é reconhecido pela doutrina que assevera:

O direito internacional privado representa, na atualidade, um dos ramos do ordenamento jurídico que mais crescem em importância e significado. Essa afirmação se baseia no fato de que os povos do mundo a cada dia interagem de modo mais evidente, e as relações individuais de caráter privado se acentuam no plano das relações jurídicas, cada vez mais mescladas de "elementos estrangeiros" (BASSO, 2009, p. 3).

A partir da afirmação de Basso (2009), parece interessante pensar em como a troca de experiências entre indivíduos de distintas nacionalidades tornou-se latente e ganhou espaço em diversas áreas: acadêmica, familiar, política, desportiva, profissional, cultural, etc ${ }^{1}$. No ramo empresarial, esse movimento também é notável: não raramente, há empresas brasileiras que se internacionalizam e, por vezes, enviam empregados brasileiros para suas filiais estrangeiras; empresas com sedes fora do Brasil buscam ampliar suas atividades no mercado brasileiro, enviando seus funcionários em designação internacional.

Sabe-se que o envio de um empregado, a trabalho, para outro país, envolve questões de âmbito legal, econômico, político, familiar, sociocultural, entre outros. Por esse motivo, o presente estudo objetiva contribuir na discussão dessa temática, focalizando alguns dos principais aspectos jurídicos atinentes à situação fiscal do expatriado durante a sua designação para outro país que não aquele do qual é oriundo, sobretudo, no tocante à taxação das rendas e dos proventos de qualquer natureza.

Considerando que ainda há uma zona cinzenta que permeia a tributação das rendas e proventos do expatriado estrangeiro, a despeito de a expatriação mostrar-se cada vez mais frequente, este trabalho tece importantes considerações a respeito dos tributos incidentes sobre a renda do expatriado que venha adquirir residência fiscal no Brasil, à luz do ordenamento jurídico brasileiro, bem como os casos em que, ainda que não se perpetre tal aquisição, há exação brasileira e se verifique a legalidade de o Brasil tributar rendas e proventos de expatriados estrangeiros.

\footnotetext{
${ }^{1}$ Nesse sentido, oportunas são as palavras de Basso (2009): "Se levarmos em conta somente o Brasil, veremos o afluxo de pessoas de todas as nacionalidades que aqui aportam e aqui estabelecem relações individuais de ordem privada. Bem como, por outro lado, o elevado número de brasileiros que deixam o país rumo à União Europeia ou aos Estados Unidos da América, para apena excursionar ou com a intenção de estudar, submeter-se a tratamento médico-cirúrgico ou, mesmo, com o espírito de lá permanecer” (BASSO, 2009, p. 4).
} 


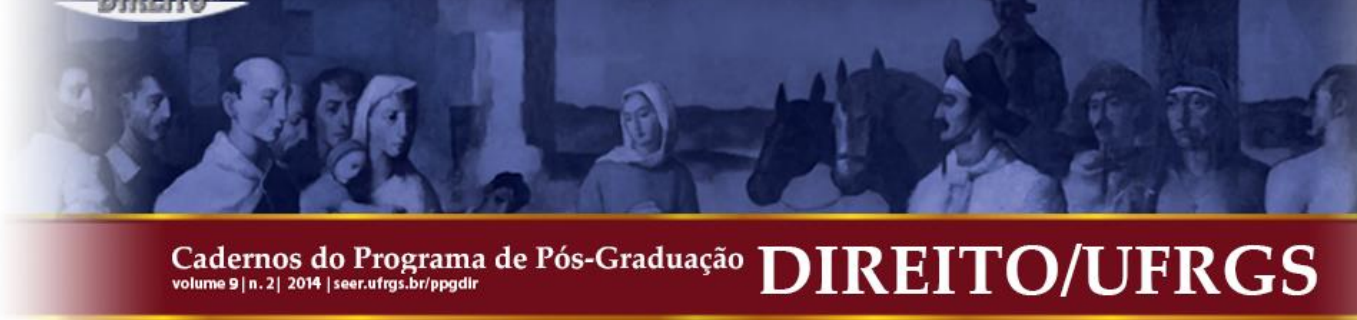

\title{
1 DEFINIÇÕES PRELIMINARES: ESTRANGEIRO, EXPATRIADO E EXPATRIAÇÃO
}

Ao propor-se uma pesquisa que dispõe acerca da tributação internacional brasileira para expatriados, primordial se faz, ainda que de forma breve, conceituar os destinatários do "fisco internacional".

Corriqueiramente, observa-se uma confusão entre "estrangeiro" e "expatriado" e, por vezes, tais predicativos são utilizados como sinônimos, embora isso seja feito erroneamente.

Estrangeiros são todas as pessoas que, por algum motivo, se encontram em um país diferente do qual ostentam nacionalidade. Já o expatriado tem seu significado vinculado à carreira profissional. O expatriado é aquele que é convidado pela empresa em que trabalha para exercer suas atividades na sede, filial ou matriz no exterior, por um tempo determinado (GADEX, 2008).

Desse conceito de expatriado ${ }^{2}$, parece razoável aceitar que o fenômeno da expatriação corresponde ao "ato ou efeito de expatriar-se ou ir residir em país estrangeiro" (FERREIRA apud RAMPI, 2009, p. 19).

A expatriação comporta inúmeras peculiaridades importantes, como as elencadas por Barbosa (2010):

\begin{abstract}
Trata-se de um processo caro, pois implica em uma série de custos para atrair os melhores candidatos; é um processo demorado, uma vez que apreender um novo código cultural e construir uma nova forma de vida não se faz de um dia o outro; é um processo ariscado, pois ainda não foi inventado um método de seleção infalível e que considere o ser humano na sua complexidade, de forma a se controlar antecipadamente e/ou posteriormente as variáveis subjetivas que afetarão ou que afetam o seu desempenho. Apesar destas restrições, estas alternativas têm sido utilizadas em larga medida pelas empresas (BARBOSA, 2010, p. 17).
\end{abstract}

O expatriado, sujeito principal desse processo, por sua vez, é entendido como o “estrangeiro-profissional que sai do seu país para viver em outro país” (RAMPI, 2009, p. 20), estando, portanto, a expatriação intimamente vinculada à transferência física de um profissional para território estrangeiro com fins profissionais, tal qual se verifica na própria legislação pátria que determina as diretrizes básicas sobre a contração de expatriados

\footnotetext{
2 Para uma leitura mais aprofundada acerca do conceito de expatriado e respectivas características e modalidades, recomendamos Tung (1981).
} 


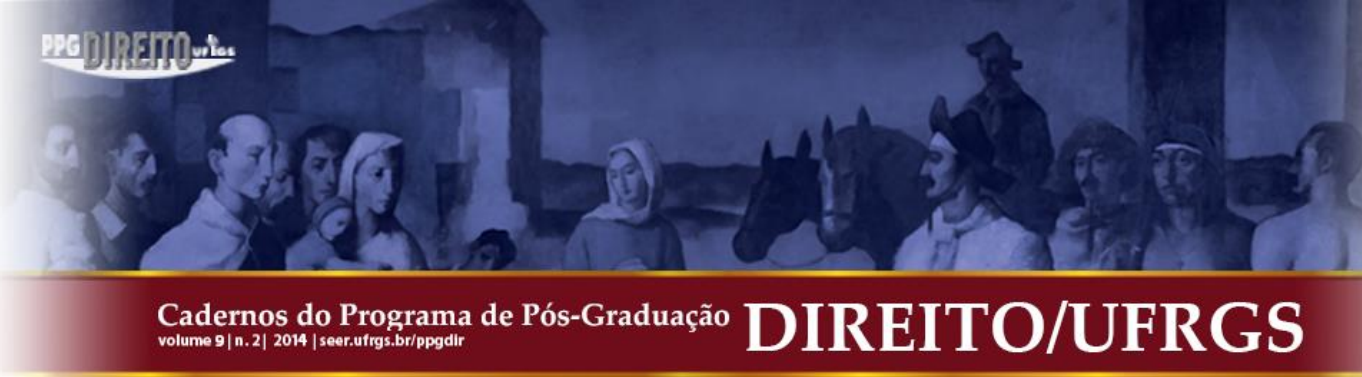

(estrangeiros ou brasileiros), isto é, no caput do artigo primeiro da Lei no 7.064/82: "esta Lei regula a situação de trabalhadores contratados no Brasil ou transferidos por seus empregadores para prestar serviço no exterior" (grifo nosso).

Na mesma direção acima mencionada, converge também a doutrina:

\begin{abstract}
A contestação a estes questionamentos e temas jurídicos aos mesmos vinculados é no que consiste o objeto do presente estudo, que parte do princípio que devemos considerar como sinônimos os termos "transferido" e "expatriado". Vamos utilizar o segundo conceito de forma mais frequente, tendo em vista que o mesmo sintetiza a idéia (sic) de transferência internacional, assim como é o termo mais utilizado no moderno âmbito empresarial-trabalhista.
\end{abstract}

Assim, o trabalhador que realiza uma transferência internacional temporária por um período superior de 12 meses, mesmo porquê ( sic), conforme o parágrafo único do art. 1, da Lei 7064/82, não são considerados expatriados aqueles empregados designados para prestar serviços de natureza transitória, por período não superior a 90 dias (MORAES, 2009, p. 97).

Isso posto, é possível afirmar que todo expatriado é um estrangeiro, mas o inverso nem sempre é verdadeiro, razão pela qual, neste estudo, não se utiliza "expatriado" e "estrangeiros" como sinônimos. Além disso, para fins de maior precisão, far-se-á uso da expressão "expatriado brasileiro" para referir-se ao indivíduo brasileiro em designação no exterior e "expatriado estrangeiro" quando o alvo se dirigir ao profissional que ostente outra nacionalidade que não a brasileira e que se encontra no Brasil por questões profissionais.

\title{
2 A RESIDÊNCIA FISCAL SOB A ÓTICA DO DIREITO TRIBUTÁRIO INTERNACIONAL DO BRASIL
}

\subsection{Da aplicação do direito internacional privado do Brasil e dos elementos de conexão na seara tributária}

No direito interno brasileiro, residência ou domicilio fiscal é regulado pelo Código Tributário Nacional (CTN) segundo o qual o contribuinte pode eleger o seu domicílio 


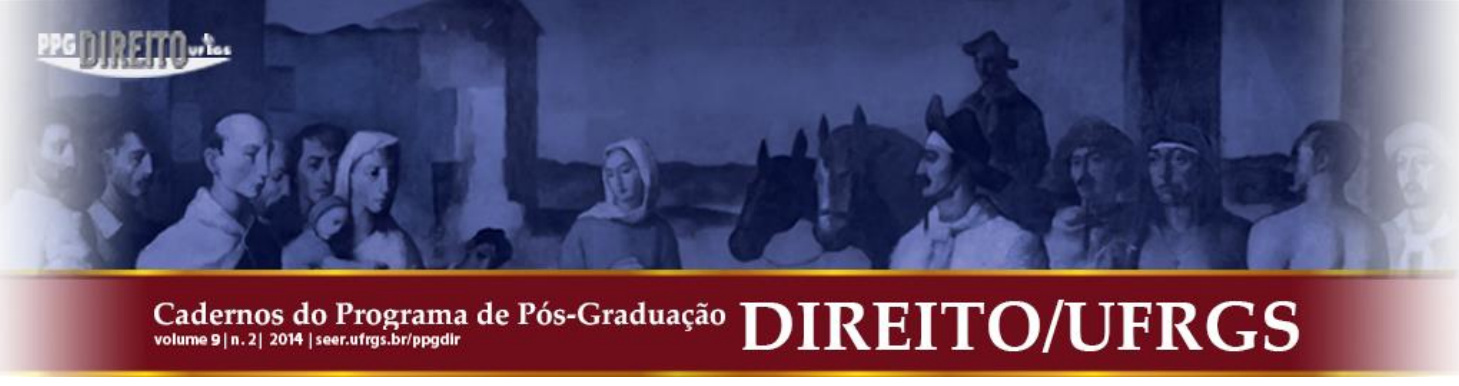

tributário - localidade onde exercerá as suas obrigações e direitos fiscais ${ }^{3}-$, exceto em situações previstas na referida lei complementar ${ }^{4}$.

Observe-se que o CTN é uma lei complementar de normais gerais, aplicadas ao direito interno brasileiro. No caso dos expatriados, as regras atinentes ao domicílio fiscal não são regidas por tal Código, mas sim pelas normas de direito internacional privado brasileiro. Essa diferenciação se deve ao fato de que a expatriação não envolve somente indivíduos subordinados a um único ordenamento jurídico, mas sim a, pelo menos, dois sistemas legais distintos. Assim, a expatriação, enquanto relação privada que o é, envolve elementos de conexão, tais como, mas não apenas, nacionalidade e território nacional, que reclamam, consequentemente, a aplicação do direito internacional privado na esfera tributária ${ }^{5}$.

Ao tratar-se de uma questão que envolve elementos de estraneidade, está-se, inicialmente, diante um conflito que acaba se estendendo para a esfera da tributação internacional. Nesse quadro, emerge, pelo menos, uma questão significativa: um indivíduo nacional e residente de um país "A" que é transferido pela empresa que trabalha para um país “B”, será tributado por qual Fisco? Será eleito o Fisco do país que é nacional (e até então de sua residência) ou o do país para o qual está se mudando?

O impasse acima não resiste a uma análise mais criteriosa e revela tratar-se de um mero e aparente conflito de normas tributárias de Fazendas Públicas de distintos Estados. Ao lançar-se mão do Direito Internacional Privado, verifica-se que a dificuldade logo cessa ao aplicar tal ramo do direito para a órbita fiscal. Tão somente observa-se um choque de interesses de arrecadações ${ }^{6}$, concurso de pretensão impositiva situada na esfera da políticafiscal e não no campo normativo ${ }^{7}$, como defende Santiago (2006):

\footnotetext{
${ }^{3}$ O Código Tributário Nacional (CTN) é, originalmente, uma lei ordinária. Contudo, quando foi recepcionado pela Constituição Federal de 1988, alçou status de lei complementar.

${ }_{4}$ A escolha do domicílio fiscal pelo contribuinte e suas exceções se encontram reguladas no artigo 127 do Código Tributário Nacional.

${ }^{5}$ A esse respeito, as palavras de Basso (2009) são importantes: "Está definido, portanto, o âmbito de atuação da disciplina: o estudo dos casos de direito privado que contenham elementos estrangeiros, como, por exemplo, o domicílio, a nacionalidade, o país sede das empresas, o local onde a obrigação se constituiu, o local onde o imóvel se encontra etc. Não entram no âmbito de estudo do DIPr questões relativas ao direito público (e nenhum de seus ramos). Daí porque nossa disciplina também poderia ser chamada de 'Direito Privado Especial', isto é, aquela que estuda e busca soluções para os ‘conflitos e leis no espaço’ em matéria privada” (BASSO, 2009, p. 6).

${ }^{6}$ Desse mesmo posicionamento, partilha Nunes (2010): "Pelo fato de, no que tange a normas de Direito Público, a orientação ser em sentido absolutamente oposto, em nosso pensar, não há espaço para conflitos de normas nessa seara. O que existe é tão somente a verificação de que um fato guarda conexão com um único ordenamento e, portanto, somente por este pode ser regulado; ou não, que guarda com mais de um e, portanto, por mais de um assim pode ser. Em matéria tributária é fácil a percepção desse espírito, mormente em sede de Direito
} 


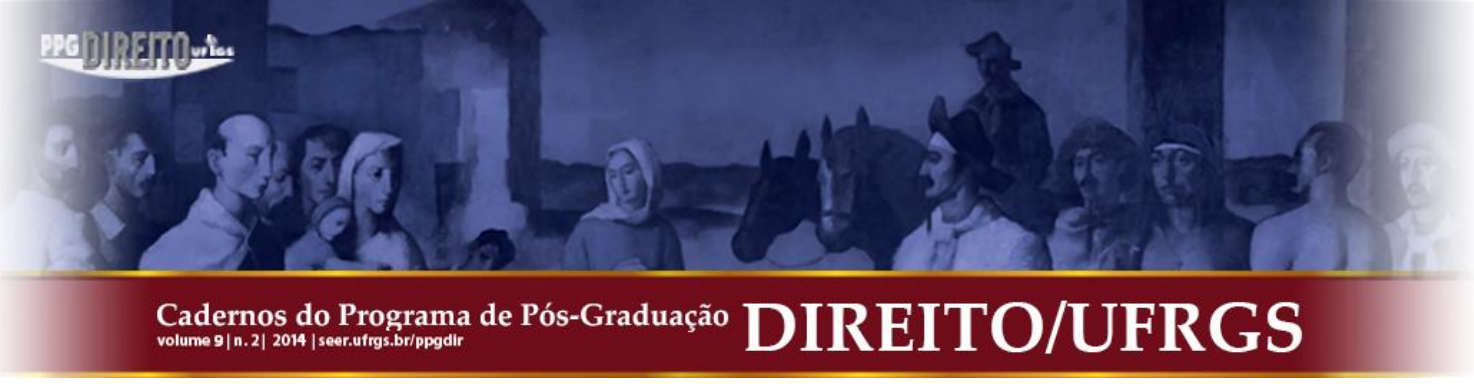

Com da conceituação acima explicitada, entende-se que os elementos de conexão relativos à tributação da renda, tocante o Direito Tributário Internacional, são, o critério pessoal e o critério objetivo/material.

Neste ponto, cabe observar que a Lei nº 9.249/95, ao determinar a tributação da renda em bases universais, utilizou o elemento de conexão relacionado à pessoa do contribuinte (critério subjetivo). Isso significa que, se o contribuinte é qualificado como residente fiscal do Brasil, sua renda deverá ser tributada nesse país, independentemente do Estado de origem das rendas e proventos a serem tributados.

A esse respeito, encontra-se eco nas palavras de Renato Nunes (2010):

Nos fatos ocorridos fora dos limites territoriais do Estado brasileiro, estes só ganham sentido se conotados com certas qualidades das pessoas. É o caso da tributação da renda em bases universais, em que isso somente se faz possível mediante a qualificação do sujeito que a aufere. Sendo o contribuinte qualificado como residente neste País, tem-se a possibilidade de suas rendas auferidas ultraterritorialmente serem tributadas no Brasil (NUNES, 2010, p. 67).

Lado outro, o critério material ou objetivo considera o local de ocorrência do fato gerador como determinante de qual Estado detém o direito de tributar a renda auferida em seu território. Novamente, Nunes (2010) acrescenta dados relevantes a este estudo:

Cuidando-se de uma conexão objetiva, material, a verificação em concreto das notas configurará a ocorrência do fato no território, autorizando o ordenamento que lhe corresponda a regulá-lo (fato). Nesse caso, a nota da hipótese que permite a localização do fato equivale ao critério de conexão, a qual se acomoda no critério espacial da regra-matriz. É porque o fato ocorreu no território do ordenamento que há relação entre eles (NUNES, 2010, p. 69).

Pelo exposto, infere-se que o elemento de conexão material respalda a tributação pelo fisco brasileiro quanto aos fatos geradores ocorridos em seu território nacional, ainda que a renda auferida seja de um não residente. É o que ocorre, por exemplo, com o pagamento de um serviço técnico realizado por não residente fiscal do Brasil que sofre retenção de Imposto de Renda na fonte pagadora, ou seja, pela pessoa física ou jurídica que realizou a importação do serviço. Também são tributados, de acordo com a conexão material, coadunando com o princípio da tributação em bases universais (princípio da residência ou conexão subjetiva), os fatos geradores de obtenção de renda e proventos, de qualquer natureza, dentro do território brasileiro, por residentes fiscais do Brasil. 


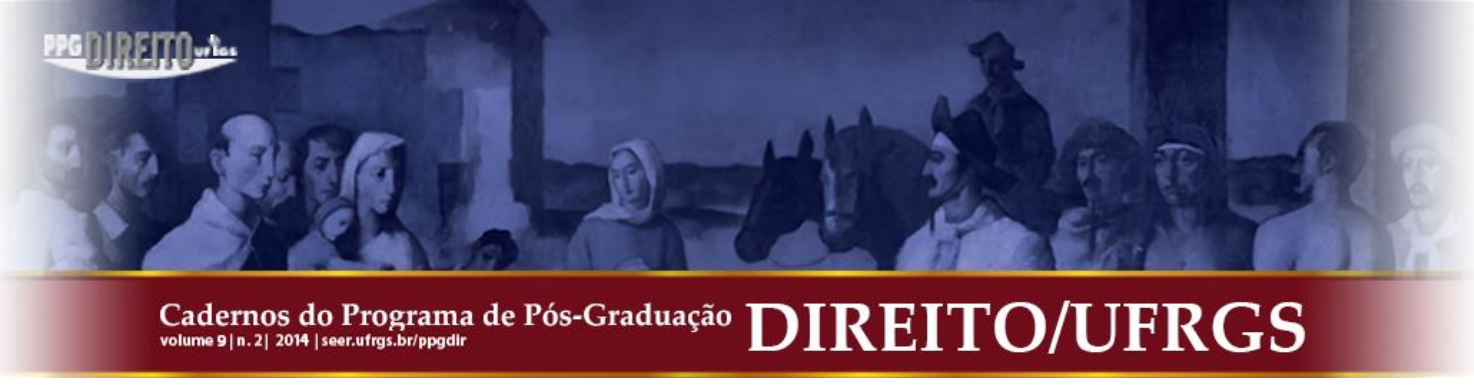

Outro importante estudioso do tema, Teixeira (2008), também destaca os elementos de conexão material e subjetivo, no entanto, nomeia-os de princípio da fonte e princípio da residência, respectivamente:

O Direito Tributário Internacional se desenvolveu, no que tange à tributação da renda, por meio da adoção de dois modelos impositivos, que se concretizaram através do princípio da fonte (source-based taxation principle) e do princípio da residência (Worldwide income principle).

O ordenamento que adota exclusivamente o princípio da fonte tributa os rendimentos dos residentes e dos não residentes, somente se produzidos ou existentes no interior do seu território. Caso a opção seja pelo princípio da residência, opera-se uma distinção entre residentes e não residentes, sendo que esse último é tributado, na grande maioria dos casos, pelos rendimentos produzidos no interior do País - ou seja, com relação aos não residentes aplica-se o princípio da fonte. Mas, no que se refere aos residentes há uma tributação dos rendimentos globais, não interessando o lugar onde os mesmos são produzidos. Os residentes são tributados pelos rendimentos auferidos internamente, bem como por aqueles oriundos do exterior (TEIXEIRA, 2008, p. 178).

Feitas tais considerações, assume-se que o elemento de conexão pessoal ou subjetivo, primeiramente analisado, é válido e utilizado não apenas pelo Brasil, mas por vários outros países, como aponta Teixeira (2008):

O Brasil, visando adotar regras padrões de tributação internacional, introduziu o princípio da renda mundial ou residência, no que se refere à tributação das pessoas jurídicas residentes no País, através do disposto no art. 25, da Lei n. 9.249 de 1995.

Em virtude desse diploma legal, as empresas residentes no Brasil passaram a ser tributadas em bases universais, ou seja, os rendimentos auferidos internamente e no exterior sofrem a incidência do Imposto de Renda das Pessoas Jurídicas. Assim, todos os rendimentos, de fonte interna e externa, devem ser somados e oferecidos à tributação, com base nas leis brasileiras (TEIXEIRA, 2008, p. 178) ${ }^{8}$.

Pelo até aqui exposto, parece razoável afirmar que o elemento de conexão subjetivo, amparado pelo princípio da universalidade, é válido e amplamente praticado no âmbito internacional, permitindo a tributação do contribuinte que tenha auferido renda ou proventos, independentemente do local de ocorrência do fato gerador (art. 43 do CTN), conquanto haja residência fiscal no país que pretende tributar ${ }^{9}$. Isso significa dizer, por exemplo, que um

\footnotetext{
${ }^{8}$ Em que pese a análise da doutrinadora ser voltada às pessoas jurídicas, o mesmo fundamento é válido e aplicável para as pessoas físicas.

${ }^{9} \mathrm{O}$ elemento de conexão material, conforme demonstrando nas linhas anteriores, também é válido e aplicável pelo Brasil. Contudo, tal elemento possui dois vieses: a tributação pode recair tanto sobre as rendas e proventos
} 


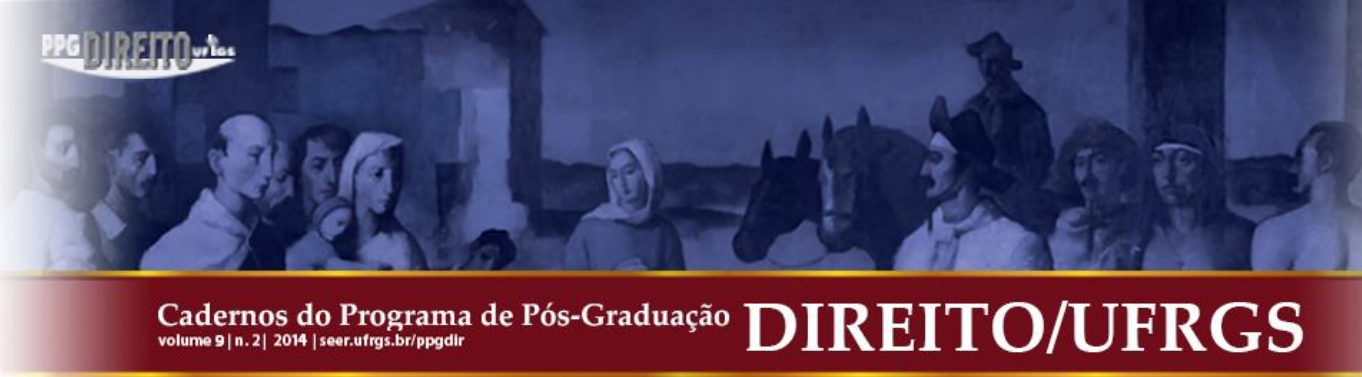

estadunidense, residente fiscal no Brasil, terá todas as rendas tributadas pelo fisco brasileiro, ainda que auferidas em fontes pagadoras não brasileiras, em razão de sua residência físcal no Brasil.

É ainda de se atentar para o fato de que o artigo 153 da Constituição Federal dispõe, em seu inciso primeiro do parágrafo segundo, que a exação sobre as rendas e os proventos será realizada em bases universais, explicitando, novamente, tal princípio que legitima o critério de conexão sob comento. Assim, tem-se que o critério de conexão subjetivo é válido e aplicado no direito internacional tributário, sendo seus elementos: a tributação - em bases universais -, a pessoa do contribuinte e a residência fiscal.

Em consonância com os argumentos ora apresentados, fica evidente que, uma vez presentes os elementos de conexão que atraiam a exação para o fisco brasileiro, em razão de constituição de residência fiscal, a legislação aplicável à expatriação, de acordo com o direito internacional privado brasileiro, será, principalmente, o Regulamento do Imposto de Renda (RIR/99 ou Decreto n. 3.000/1.999), a Instrução Normativa n ${ }^{\circ}$ 208, bem como o Estatuto do Estrangeiro (Lei n. 6.815/1.980), sendo, portanto, o estrangeiro tributado, tão logo adquira residência fiscal no Brasil, em igualdade de condição com os contribuintes nacionais. Em outras palavras, existentes os elementos de conexão, no caso, fixada a residência fiscal no Brasil, o expatriado estrangeiro está sujeito à tributação sobre suas rendas e seus proventos em bases universais, de acordo com as alíquotas progressivas, determinadas pela legislação tributária brasileira.

Nesse diapasão, verifica-se ser de suma importância identificar qual é o elemento de conexão presente na situação concreta, a fim de se verificar a qual fisco o expatriado se torna contribuinte e qual será a base de cálculo da sua exação: as rendas universalmente consideradas ou apenas as rendas auferidas do fato gerador ocorrido em um determinado território nacional. Corroborando com o exposto, Teixeira (2008) tece considerações relevantes quanto à pessoa jurídica, igualmente aplicáveis à pessoa física:

Dessa forma, mostra-se de suma importância determinar se uma empresa é ou não residente no Brasil, porque uma vez sendo residente ela será tributada pela totalidade

\footnotetext{
de não residentes quanto nos rendimentos de residentes. Como o presente trabalho trata-se de tributação das rendas e proventos de qualquer natureza de expatriados, que adquiriram residência fiscal no Brasil, o critério de conexão material coaduna com o critério subjetivo, também conhecido como princípio da tributação em bases universais ou princípio da residência, razão pela qual será abordado com maior profundidade o elemento de conexão pessoal.
} 


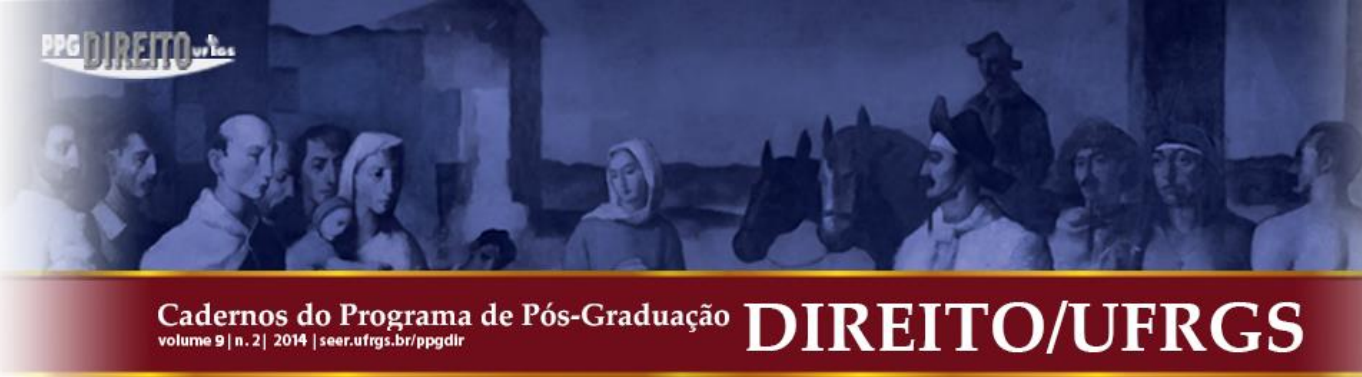

trabalhista e previdenciária brasileira, bem como arcar com os encargos trabalhistas e previdenciários, em razão do vínculo empregatício formado.

Considerando que o expatriado entre no Brasil com contrato de trabalho previamente acordado, será o mesmo considerado residente fiscal a partir de sua entrada física em território brasileiro, conforme determina o artigo 19, inciso primeiro, do Decreto 3.000/1999, in verbis:

Art. 19. Sujeitar-se-á à tributação pelo imposto de renda, como residente, a pessoa física proveniente do exterior que ingressar no Brasil, com visto temporário (Lei no 9.718, de 1998, art. 12):

I - para trabalhar, com vínculo empregatício, em relação aos fatos geradores ocorridos a partir da data de sua chegada;

(...)

Diferente é a situação do estrangeiro que entra em território brasileiro sem possuir contrato de trabalho com pessoa jurídica brasileira. Nesse caso, o funcionário expatriado será considerado contribuinte do imposto de renda no Brasil, em caso de permanência por período igual ou superior a cento e oitenta e quatro dias, consecutivos ou não, em um lapso temporal de até doze meses, devendo observar as obrigações fiscais para com leão brasileiro, a partir da configuração de seu status como residente fiscal, conforme também determina o Decreto $\mathrm{n}^{\mathrm{o}}$ 3.000/99:

\footnotetext{
Art. 19. Sujeitar-se-á à tributação pelo imposto de renda, como residente, a pessoa física proveniente do exterior que ingressar no Brasil, com visto temporário (Lei no 9.718 , de 1998, art. 12):

(...)

II - por qualquer outro motivo, e aqui permanecer por período superior a cento e oitenta e três dias, consecutivos ou não, contado, dentro de um intervalo de doze meses, da data de qualquer chegada, em relação aos fatos geradores ocorridos a partir do dia subsequiente àquele em que se completar referido período de permanência.

(...)
}

Diferentemente disso, caso o estrangeiro entre com visto temporário, sem contrato de trabalho, e durante sua estada seja celebrado um acordo de trabalho com empresa brasileira, o mesmo será considerado sujeito à taxação do leão brasileiro, a partir da formalização do vínculo de trabalho, ainda que não tenha gozado do benefício da "carência" de cento e oitenta e três dias - previstos para aqueles que possuem visto temporário sem contrato de trabalho -, já que houve uma mudança em seu perfil, ou seja, de estrangeiro passa à condição de expatriado. 


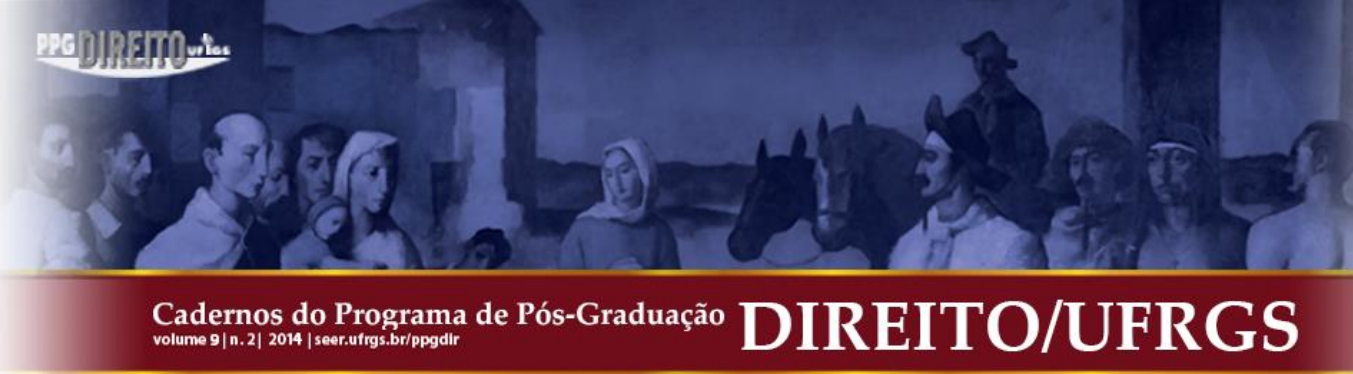

\subsubsection{Visto Temporário para assistência técnica e cooperação técnica}

A situação do visto temporário - previsto no artigo 13, inciso V da Lei $n^{\circ}$ 6.815/80 e regulamentado pela Resolução Normativa $n^{\circ} 61$ do Conselho Nacional de Imigração -, dispõe a respeito da transferência de tecnologia e prestação de assistência técnica. O que determinará a condição de residência fiscal do expatriado que preste assistência ou cooperação técnica será sua permanência igual ou superior a 184 (cento e oitenta e quatro) dias, ainda que o seu visto seja válido por maior lapso temporal. O prazo inicial do visto sob comento é de doze meses, mas, caso o expatriado deixe o território brasileiro nos 183 (cento e oitenta e três) dias subsequentes ao da sua entrada, não retornando durante os doze meses subsequentes, não configurará a residência para fins de tributação de imposto de renda no Brasil, sendo aplicável a determinação do artigo 19, inciso segundo, do Decreto 3.000/1999.

\subsubsection{Visto Permanente}

O visto anunciado na Resolução Normativa $\mathrm{n}^{\circ}$ 95, de 2011, chamado de visto permanente, é destinado aos funcionários que exercem cargos de gerência e direção, ou seja, cargos de confiança de uma empresa. Tais expatriados são enviados ao Brasil com a finalidade de representarem legalmente a filial brasileira e devem ser ter seus vistos solicitados pela subsidiária brasileira junto ao Ministério do Trabalho e Emprego.

O principal requisito a ser observado para pleitear a concessão do visto brasileiro é o investimento, por parte da empresa estrangeira, do montante equivalente a, no mínimo, seiscentos mil dólares americanos por executivo expatriado que necessite de tal documento, o que se faz por meio de investimento em moeda estrangeira junto ao Banco Central do Brasil. Entretanto, pode-se também solicitar a permissão de permanência após serem investidos cento e cinquenta mil dólares americanos no Brasil e um plano sólido e tangível para gerar, ao menos, dez novos postos de empregos, durante os dois anos subsequentes à abertura da filial brasileira ou da entrada física do executivo expatriado. 


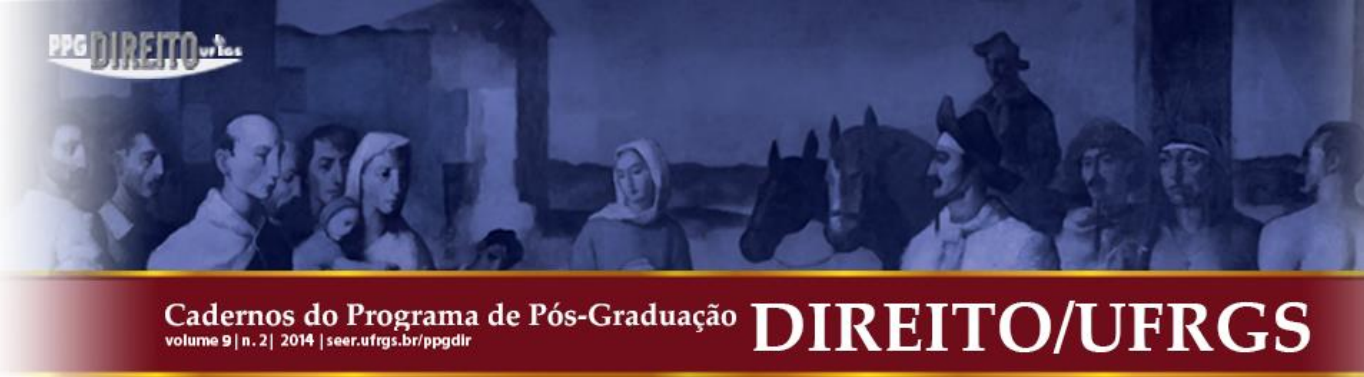

Vale ressaltar que o visto permanente também pode ser requerido em benefício de expatriado convidado por empresa nacional, para exercer função executiva no território nacional. Nesse caso, obviamente, não há que se falar em apresentação de comprovante de investimento de moeda estrangeira no Brasil, tendo em vista se tratar de empresa nacional importando mão de obra qualificada.

Ainda um último caso de visto permanente, regulado pela Resolução Normativa ${ }^{\circ}$ 84, de 2009, merece atenção: o de estrangeiro, pessoa física, interessado em investir o montante mínimo de cento e cinquenta mil dólares estadunidenses no setor produtivo brasileiro, quer seja por meio de empresa já existente, quer seja por meio de constituição de uma nova pessoa jurídica de direito privado brasileira.

Pela análise dos critérios estabelecidos para a concessão do visto permanente e os perfis traçados dos beneficiários de tal documento, pode-se afirmar que dificilmente o expatriado executivo não será residente fiscal do Brasil. Isso porque uma empresa, em situações normais, não introduzirá um montante vultoso de capital para adquirir um visto permanente para um alto funcionário se este possuir uma designação de curta duração, em que não seja possível o retorno de considerável lucro, após os altos dispêndios realizados para a alocação do expatriado em território diverso do de sua origem.

É digno de nota que, uma vez sob a condição de residente permanente, o expatriado passará a ter todos os direitos e as obrigações para com o fisco brasileiro, assim como todos os nacionais do território em que se encontra.

\section{TRATADOS INTERNACIONAIS TRIBUTÁRIOS}

Diante da situação de expatriação, pode ocorrer que algum funcionário em designação internacional não perca a condição de residente fiscal do seu país de origem, mas, concomitantemente, adquira a residência fiscal no Brasil. Assim, torna-se imprescindível a análise dos tratados para evitar a dupla tributação em um contexto de dupla residência fiscal pelo mesmo contribuinte.

De acordo com a Convenção de Viena, datada de 1969, o tratado é "um acordo internacional celebrado por escrito entre Estados e regido pelo Direito Internacional, quer 


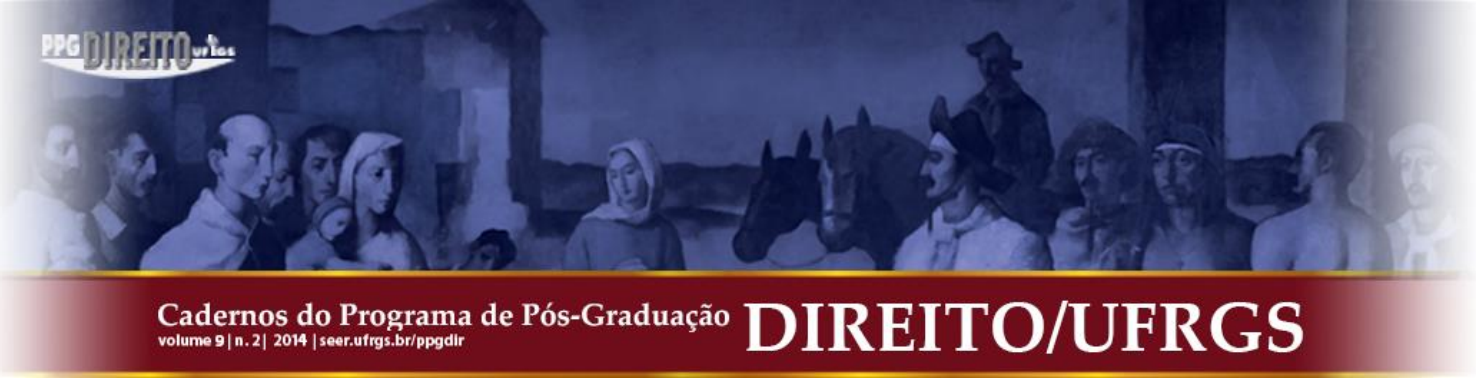

conste de um instrumento único, quer de dois ou mais instrumentos conexões, qualquer que seja sua denominação particular" (art. $2^{\circ}$, Convenção de Viena).

Além disso, considera-se que o tratado

é o meio pelo qual os sujeitos da comunidade jurídica internacional regulam a sua conduta recíproca, vale dizer, a conduta dos seus órgãos e súditos em relação aos órgãos e súditos dos outros. É o acordo de vontades através do qual são criadas normas que impõem deveres e conferem direitos aos Estados contratantes (KELSEN, 1984, p. 431).

Assim, lançando mão da teoria geral dos tratados, pode-se construir o conceito de tratado internacional tributário como sendo o acordo de vontades entre dois ou mais Estados, estabelecendo condutas, direitos e obrigações mútuas em matéria de fiscalização, arrecadação e competência tributária, a fim de que os nacionais dos Estados envolvidos não incorram em excesso de exação.

Os tratados em matéria de direito tributário, no Brasil, são tão importantes ${ }^{11} \mathrm{e}$ valorizados que o próprio Código Tributário Nacional, desde sua promulgação, dispõe em seu artigo 98 que "os tratados e as convenções internacionais revogam ou modificam a legislação tributária interna, e serão observados pela que lhes sobrevenha" ${ }^{" 12}$. Na verdade o que se tem não é a revogação nem a modificação da legislação interna, mas sim a suspensão de aplicabilidade da norma nacional, em favor da norma internacional, nos casos de conflito entre ambas.

Em face disso, ressaltando a importância do artigo 98 do CTN, Tôrres (2004) explicita:

Em particular, quanto às convenções de Direito Internacional Tributário, temos a legislação infraconstitucional um dispositivo específico predisposto para definir a relação entre aquelas e o ordenamento interno. Trata-se do art. 98 do CTN que

\footnotetext{
${ }^{11}$ Exaltando a importância dos tratados em matéria internacional, Xavier (1995) afirma que "Dentro das fontes internacionais do Direito Tributário, os tratados ocupam lugar de primordial relevo. De há muito, com efeito, se celebram convenções internacionais que, versando embora essencialmente matérias de outra natureza, contemplam, acidental ou acessoriamente, disposições tributárias: basta pensar nos acordos de comércio, nos que visam a formação de uniões aduaneiras ou zonas de comércio livre, nos que regulam os portos marítimos, os aeroportos, a viação rodoviária, a navegação aérea, o trânsito e baldeação, o serviço postal, a emigração, a proteção de investimentos, a cooperação cultura, científica ou militar, ou as convenções relativas às imunidades diplomáticas e consulares ou ao regime fiscal das organizações internacionais e seus empregados" (XAVIER, 1995, p. 87).

12 A esse respeito, cabe destaque o que afirma Sacha Coêlho (2004): "E dispõe, assim, exatamente para dar credibilidade e garantia aos terceiros países acordantes. Seria inútil o Estado brasileiro celebrar acordos sem um minimum de estabilidade jurídica" (COÊLHO, 2004, p. 578).
} 


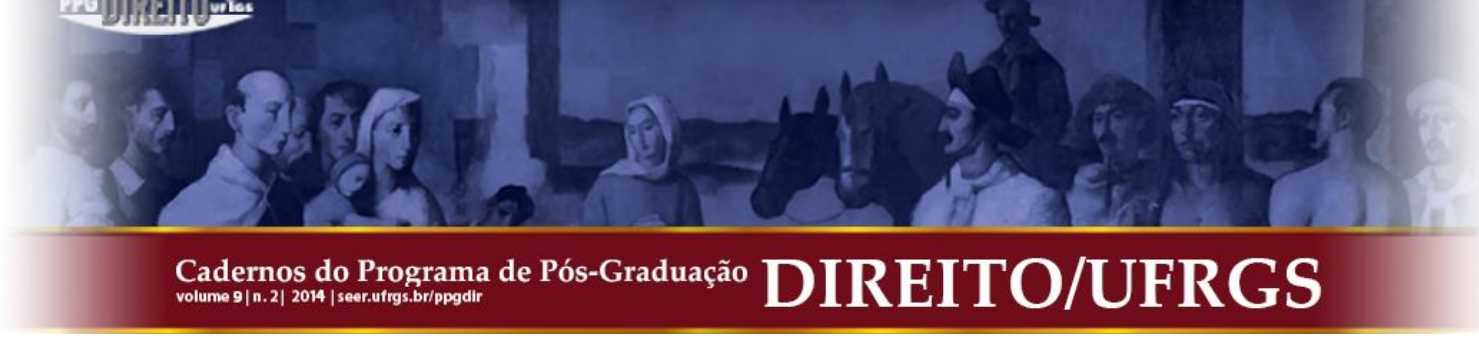

REMESSA DE RECURSOS A EMPRESA NO EXTERIOR, COMO REMUNERAÇÃO POR SERVIÇOS PRESTADOS. CONVENÇÃO CONTRA A DUPLA TRIBUTAÇÃO. NORMA DA LEGISLAÇÃO INTERNA QUE SE MOSTRA POSTERIOR E MAIS ESPECÍFICA. 1. Pretensão cabível em sede de mandado de segurança, pois visa a afastar os efeitos concretos decorrentes de ato normativo. Legitimidade da impetrante, que figura como responsável tributário pelo recolhimento do tributo e, portanto, possui relação tributária com o Fisco. 2. De acordo com a jurisprudência dominante no Supremo Tribunal Federal, os tratados, no Brasil, quando adentram o ordenamento jurídico, o fazem com o mesmo status hierárquico das leis ordinárias (RE 80.004/SE). Assim, qualquer conflito que se dê entre um tratado internacional e uma lei interna, de fato, será resolvido de acordo com os critérios de especialidade e de cronologia, por tratarem de normas de igual hierarquia. 3. No caso, temos o disposto no art. 7o da Convenção contra a dupla tributação, celebrada entre o Brasil e os Países Baixos (internalizada em nosso ordenamento pelo Decreto $\mathrm{n}^{\circ} 355$, de 2 de dezembro de 1991), em confronto com o art. 7o da Lei ${ }^{\circ}$ 9.779/99. 4. Pelo critério temporal, a norma da Lei $\mathrm{n}^{\circ}$ 9.779/99 prevalece sobre o tratado, pois é posterior. 5. Também pelo critério da especialidade deverá ser aplicada a regra da lei interna (art. 7o da Lei $n^{\circ}$ 9.779/99), pois, no caso em tela, os valores que estão sendo remetidos ao exterior decorrem de contrato que respeita a serviços de consultoria em informática, situação que se subsume à norma daquela lei. 6. Inexiste violação ao art. 98 do CTN que, afinal, estabelece a prevalência dos tratados nacionais sobre a legislação interna justamente pelo fato de estes possuírem disposições específicas com relação àquela. Porém, além de a legislação interna ser mais específica que o tratado internacional, a própria aplicação da Convenção ao caso concreto resta discutível, o que importa a nãoaplicação do art. 98 do CTN. 7. Em se tratando, nestes autos, de prestação de serviços constante e duradoura, em razão da necessidade de não-interrupção do trabalho de manutenção realizado pela empresa, constata-se a existência de estabelecimento permanente da empresa estrangeira em nosso território, corroborando a inexistência de bitributação. 8. Apelação improvida. (RIO DE JANEIRO, TRF2, AMS 200151010224788, Rel. Des. Federal Luiz Antônio Soares, 2009) (grifo nosso).

Diante do impasse gerado, cabe a retomada de uma questão frisada anteriormente: o Código Tributário Nacional, lei maior de regulamentação em matéria fiscal no Brasil, depois da Constituição Federal, reconhece a supremacia dos tratados em detrimento da legislação interna em caso de aparente conflito. Assim, se a lei que regulamenta a sistemática tributária no País determina qual é o critério de aplicação ante um conflito entre legislação nacional e tratado internacional, não há que se falar em utilização de critérios genéricos para antinomias, como a especialidade, hierarquia e cronologia ${ }^{14}$. Ademais, a Convenção de Viena de 1969,

\footnotetext{
${ }^{14}$ Para Luciano Amaro, "o conflito entre a lei interna e o tratado, resolve-se, pois, a favor da norma especial (do tratado), que excepciona a norma geral (da lei interna), tornando-se indiferente que a norma interna seja anterior ou posterior ao tratado. Este pondera em ambos os casos (abstraída a discussão sobre se ele é ou não superior a lei interna) porque traduz preceito especial, harmonizável com a norma interna" (AMARO apud TÔRRES, 2001, p. 576-577). Nessa toada, Xavier (1995) dispõe: "ora, se os tratados são recebidos na ordem interna como tratados e não como leis internas, ao abrigo de uma cláusula geral de recepção plena, isso significa que só podem ser celebrados, revogados ou denunciados pelos mecanismos que lhes são próprios e não pelos mecanismos que valem para as leis internas. É precisamente nesta impossibilidade de a lei ordinária interna revogar ou denunciar um tratado internacional que consiste a supremacia hierárquica deste último" (XAVIER, 1995, p. 110).
} 


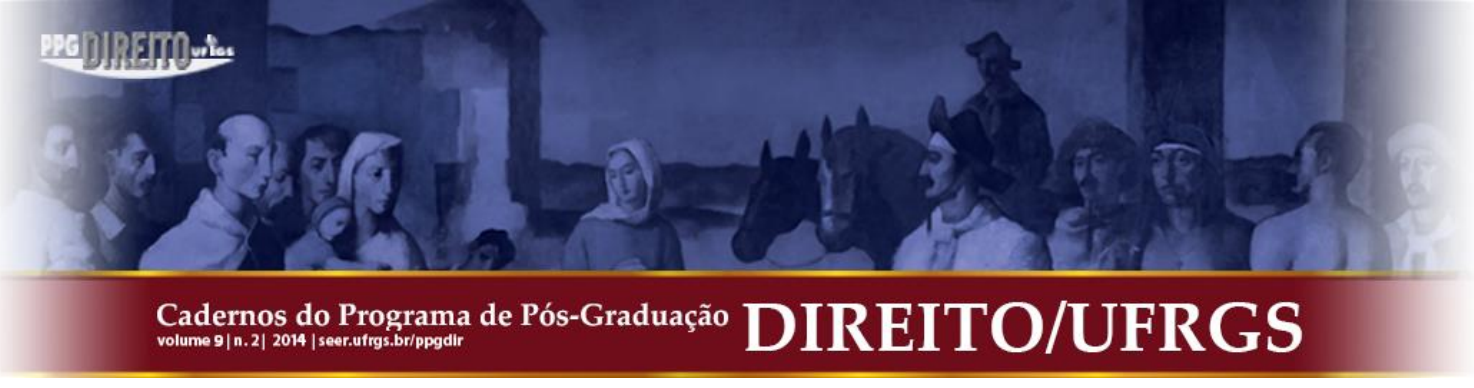

que prevê as diretrizes genéricas de aplicação e utilização dos tratados, dispõe, em seu artigo 27, que "uma parte não pode invocar as disposições de seu direito interno para justificar o inadimplemento de um tratado (...)".

Considerando que o Brasil é signatário da referida convenção, percebe-se que, na decisão colacionada no parágrafo anterior, houve um flagrante descumprimento tanto à Convenção de Viena quanto ao Tratado com os Países Baixo, bem como infringência ao pacta sunt servanda ${ }^{15}$, de forma injustificada.

Situação que, em termos práticos, se assemelha ao efeito alcançado por meio dos tratados, mas que com estes não se confundem, diz respeito à reciprocidade de tratamento em matéria fiscal. O Brasil reconhece o direito do expatriado estrangeiro que se encontra em situação de dupla tributação, permitindo que o montante pago ao fisco estrangeiro seja compensando do valor a ser pago ao fisco brasileiro, desde que o mesmo fisco internacional permita tal compensação, em igualdade de tratamento e condições, ao expatriado brasileiro que já tenha sido tributado no Brasil e que também deve recolher exação aos cofres públicos do país em que se encontra residindo. É o que ocorre, atualmente, entre o Brasil e a Alemanha, os Estados Unidos e o Reino Unido, pois se reconhece a reciprocidade de tratamento. Caso o contribuinte queira avocar, no Brasil, a reciprocidade existente com outro país, deve apresentar à representação diplomática brasileira uma cópia autenticada da publicação oficial da legislação estrangeira que preveja expressamente esse benefício, acompanhada de tradução juramentada.

Quanto à importância dos tratados em matéria fiscal, oportuna mostra-se a transcrição das palavras de Heleno Tôrres (2004):

Entre as normas de Direito Internacional Tributário, encontram-se as normas
convencionais que introduzem conceitos próprios específicos (como exemplo, o de
estabelecimento permanente), certos critérios típicos para o tratamento das
categorias de rendimentos e impostos previstos, o princípio da não discriminação, as
prescrições que regulam o procedimento amigável e assistência administrativa, os
métodos adequados para eliminar a bitributação internacional etc. De fato, é um
grupo muito restrito de normas, as que são exclusivamente de Direito Internacional

15 A esse respeito, Torres (2004) esclarece: "Em homenagem ao princípio do pacta sunt servanda, uma convenção internacional vincula os Estados que a tenham celebrado, internacionalmente, no limite temporal fixado para sua vigência, ou sine die, caso não se decrete sua inaplicabilidade (denúncia); motivo pelo qual este princípio deve ser aceito como o pressuposto essencial para a prevalência de aplicabilidade dos acordos internacionais, haja vista a sua carga semântica fazer supor que, uma vez incorporado um acordo ao ordenamento jurídico, nenhuma norma interna poderá decidir signatários são mantidas em forma de reciprocidade, põe-se como inconcebível qualquer desrespeito unilateral” (TÔRRES, 2001, p. 582). 


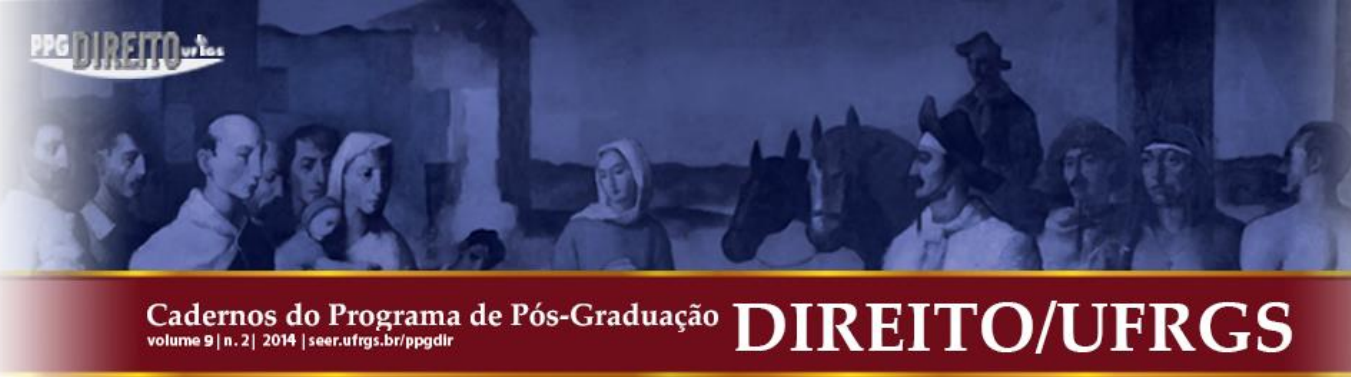

Tributário, porque a maioria das normas convencionais é, necessariamente, dependente dos respectivos sistemas internos.

Como diz Garbarino, o Direito Internacional Tributário, em sua acepção mais correta, é o que se poderia chamar de direito dos tratados internacionais em matéria tributária.

Mas bem entendido: não são normas internacionais porque dotadas de uma hipótese
de incidência impositiva, cujo critério material possibilite o surgimento in concreto
de um fato-evento gerador de tributos que, formando uma "obrigação tributária
internacional", possa vir a ser cobrado internacionalmente, onde quer que ocorra;
mas, outrossim, porque dizem respeito às relações entre Estados em matéria
tributária, particularmente para o tratamento coordenado das atividades impositivas,
distribuição harmônica do Poder de Tributar entre si e resolução dos concursos
impositivos e dos problemas de fraudes internacionais.

Somente estas normas, presentes nas convenções de Direito Internacional Tributário, em seu ambiente de princípios e normas de Direito Internacional, em matéria fiscal, possuem o condão de resolver tais concursos, porque ofertam critérios de decisão que não pertencem ao direito interno de certos Estados, limitadamente, à medida que são oriundas de relações bilaterais que estabelecem em parte limitando, em parte modificando as normas de direito interno de ambos, em função dos elementos de estraneidade que as normas disciplinam (TÔRRES Apud COÊLHO, 2004, p. 92-93).

\section{A "EQUIDADE FISCAL": A POLÍTICA DE EQUALIZAÇÃO FISCAL}

Uma questão que não se pode deixar de abordar, ainda que resumidamente, diz respeito à diferença de ônus tributário que um expatriado frequentemente se depara quando deixa o seu país para trabalhar em outro.

Ao encarar a realidade da residência fiscal no Brasil, muitos colocam em xeque a aceitação da designação internacional ofertada, já que a tributação brasileira é considerada elevada. Para que tal diferença de exação não seja empecilho para o aceite, muitas empresas têm implantado uma política de equalização fiscal.

Por meio da equalização, busca-se praticar ações que visam a igualar algo ou alguém semelhante, por determinado motivo, a outrem. É nessa esteira que se insere a equalização fiscal: a tentativa de, por meio de uma política fiscal de iniciativa privada, tornar iguais as cargas tributárias de pessoas sujeitas a taxações diferentes, pelos fiscos a que se submetem, em razão de expatriação, de modo a não haver diferenciação de ônus tributário em relação àquele originalmente suportado pelo trabalhador em seu país de origem.

Cabe assinalar o que afirma Ponte (2011) a respeito do processo de equalização, ainda que se dirija ao expatriado brasileiro, pois se entende que as considerações feitas também se aplicam ao expatriado estrangeiro: 


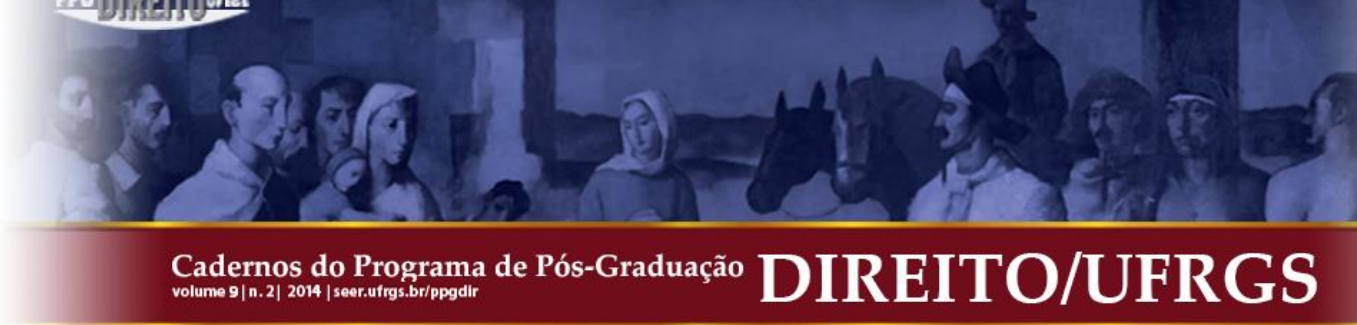

Com esse cenário, um bom planejamento fiscal é essencial para toda e qualquer transferência internacional. A boa notícia é que a maioria das empresas está atenta ao tema e oferece, em suas políticas, algum tipo de apoio. Entre os amparos fiscais concedidos, destacam-se dois tipos. Na "proteção fiscal", a companhia arca com o ônus de tributação do expatriado durante o período de transferência, somando à remuneração o valor dos impostos.

Já a "equalização fiscal", prática mais utilizada, é a garantia, por parte da empresa, de que o expatriado pagará o mesmo nível de impostos, no país de destino, que pagaria caso permanecesse no Brasil. A diferença entre o imposto real e o hipotético é reembolsada pela empresa ao expatriado.

$\mathrm{Ou}$, se o expatriado for pagar menos imposto fora, ocorre o inverso. Isso anula os prejuízos ou vantagens fiscais decorrentes da transferência. Diante de uma expatriação, vale a pena conferir qual é a política adotada pela companhia em que trabalha e sempre levar em consideração o tema dos impostos. Assim, evitam-se frustrações e cresce a chance de sucesso para você e para a empresa. (PONTE, 2011).

Pelo exposto, verifica-se que a equalização é arquitetada para que não haja enriquecimento às custas de carga tributária menos onerosa no país de destino, tampouco prejuízo sobre o rendimento devido à maior taxação no país para o qual o funcionário é transferido. Assim, caso o empregado enfrente tributação superior do que àquela do seu país originário, as empresas que adotam a política de equalização fiscal reembolsam ao seu expatriado a onerosidade excessiva suportada por este. Sendo a realidade oposta, havendo uma tributação mais branda no país receptor, o empregado será o responsável por reembolsar à empresa o suposto "lucro" que auferiu em razão de menor taxação.

Essa forma de compreender a equalização fiscal também encontra abrigo nos estudos de Marta Álvarez-Novoa e por ela é valorizada:

(...) a equalização fiscal é um sistema de compensação cujo objetivo é garantir ao trabalhador a mesma carga fiscal que teria caso não tivesse sido enviado ao exterior. Em outras palavras, o que se pretende é assegurar ao empregado, enviado ao exterior, o mesmo volume de impostos, nem mais nem menos, que teria se estivesse em seu país de origem. Portanto, a questão fiscal não deveria ser argumento a favor e nem contra a decisão de aceitar um trabalho fora do país (ÁLVAREZ-NOVOA Apud TÃO..., 2009).

Ou seja, independentemente do regime tributário que recaia sobre rendimentos e proventos, o expatriado não sentirá diferença no seu rendimento líquido, já que a retenção a ser sofrida será a mesma que arcaria se permanecesse em sua pátria, havendo uma verdadeira neutralização de eventuais diferenças de tributação que poderiam existir. Por isso, pode-se 


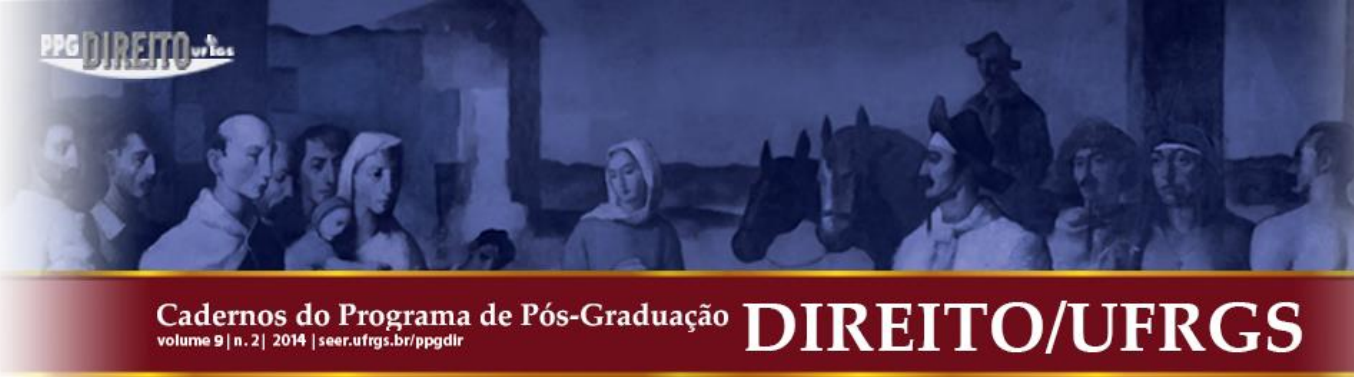

positivar a ideia de que a equalização fiscal não se trata de um benefício fiscal oriundo da iniciativa privada, tampouco um meio mais gravoso sob a ótica fiscal, mas sim de um meio de se praticar uma "equidade fiscal".

Para que a equalização seja levada a cabo, a empresa retém um "imposto hipotético", calculado na taxação que o expatriado estaria sujeito em caso de permanência em seu país, havendo o pagamento pela empresa dos impostos incidentes pela renda do expatriado no país em que o mesmo se encontra a trabalho. Após o fim do ano fiscal, é feito um "encontro de contas" em que são apurados os valores efetivamente pagos pela empresa, em nome do expatriado, ao fisco do país da designação internacional, e verifica-se o valor dos impostos federais pagos pelo expatriado, em seu país de origem, durante o mesmo período, a fim de proceder-se às compensações. Feito isso, caso o saldo remanescente seja maior do que o imposto hipotético, a empresa reembolsará o seu funcionário - pois suportou uma exação maior do que estaria sujeito, se tivesse permanecido no seu país de origem - ou, em situação oposta, o empregador será credor do montante correspondente à diferença dos valores sob comento.

\section{CONSIDERAÇÕES FINAIS}

A argumentação ora tecida torna legítima a ação de tributação, por parte da Fazenda Pública brasileira, em bases universais, dos rendimentos de estrangeiros que adquiram residência fiscal em seu território nacional. Em situação de existência de elemento de estraneidade, utilizam-se os princípios do Direito Internacional Privado que, em matéria tributária, exsurgem inseridos no Direito Tributário Internacional, segundo o qual há critérios de conexão que levam em consideração a pessoa do contribuinte (critério subjetivo).

Soma-se a isso o fato de que a tributação dos expatriados estrangeiros, no Brasil, está estreitamente relacionada ao período de presença (ou ausência) física no território brasileiro, bem como ao tipo de visto ostentado pelo mesmo.

Evidenciada a relação lapso-temporal e o tipo de visto, além da presença dos elementos de conexão, compreende-se é de suma importância verificar a configuração da condição de residente (ou não) fiscal do Brasil, com vistas à definição do momento a partir do 


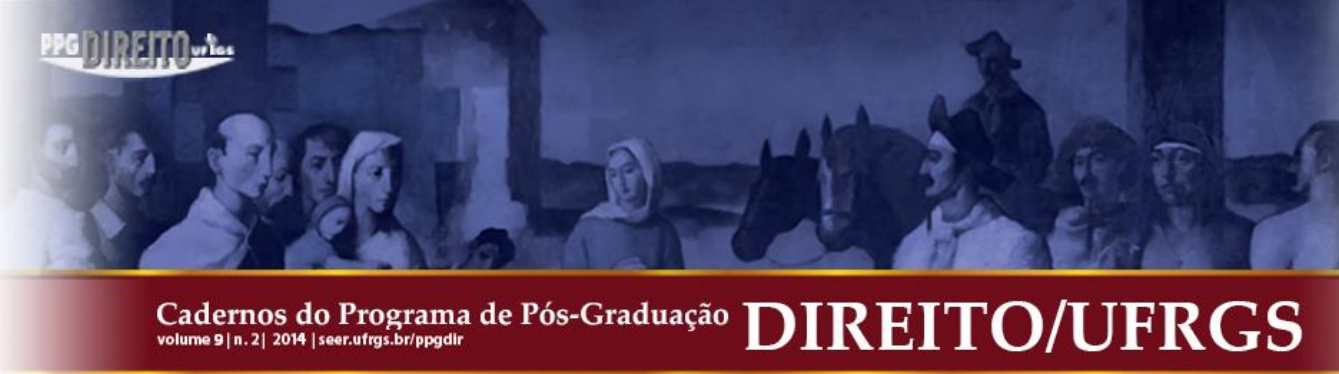

qual um expatriado estrangeiro estará sujeito à taxação brasileira e seus consectários (obrigações acessórias).

Merece atenção especial a situação do expatriado estrangeiro que adquire residência fiscal no Brasil, sem ter perdido a condição de contribuinte tributário em seu país de origem, pois fica configurada a dupla tributação sobre o mesmo fato gerador (auferir renda ou proventos de qualquer natureza). Para essa circunstância, o Brasil possui, em vigência, trinta acordos com outros Estados em que se visa a, via de regra, compensar o imposto pago entre os países signatários ou a regulamentar situações em que um fisco deixará de tributar em benefício do outro e vice versa. Há também os contextos de reciprocidade de tratamento nos quais o Brasil permite a compensação de tributos sobre a renda, pagos no exterior, desde que o país estrangeiro permita o mesmo tratamento, em seu território nacional, aos brasileiros ali expatriados.

Diante do exposto, pode-se concluir que a expatriação está ligada a uma transferência pautada em um lapso temporal significativo e, não a uma estada transitória e curta para uma mera prestação de serviço. Ao revés, percebe-se que a legislação considera expatriado aquele funcionário estrangeiro que é transferido para o Brasil, com animus de longa permanência, conforme se depreende da Lei $\mathrm{n}^{\circ} \mathbf{7 . 0 6 4}$, cujo parágrafo único do artigo primeiro dispõe que "fica excluído do regime desta Lei o empregado designado para prestar serviços de natureza transitória, por período não superior a 90 (noventa) dias (...)”.

Por essa configuração, percebe-se a importância da conceituação de expatriação para o campo tributário. Se o expatriado é um estrangeiro que se muda para o Brasil, a fim de desenvolver um trabalho importante e do "alto escalão" corporativo, por exemplo, passa a ter a tutela trabalhista em igualdade de condições em relação aos trabalhadores brasileiros, razão pela qual usufrui dos serviços públicos brasileiros. Dentre eles, pode-se destacar-se a fiscalização das empresas empregadoras, pelo Ministério do Trabalho e Emprego, evitando abusos contra os trabalhadores, protegendo os direitos dos empregados nacionais e expatriados, indistintamente. Ou seja, com a expatriação há o efetivo desfrute dos serviços públicos que são prestados pelo Estado e que, portanto, devem ser suportados por todos aqueles que deles se beneficiam. Assim, é legítimo ao Fisco brasileiro tributar as rendas e os proventos, de qualquer natureza, dos expatriados estrangeiros que adquirem residência fiscal no Brasil, em igualdade de tratamento dispensado aos cidadãos brasileiros, e que se valem igualmente dos mesmos serviços estatais. Portanto, uma vez configurada a residência fiscal, 


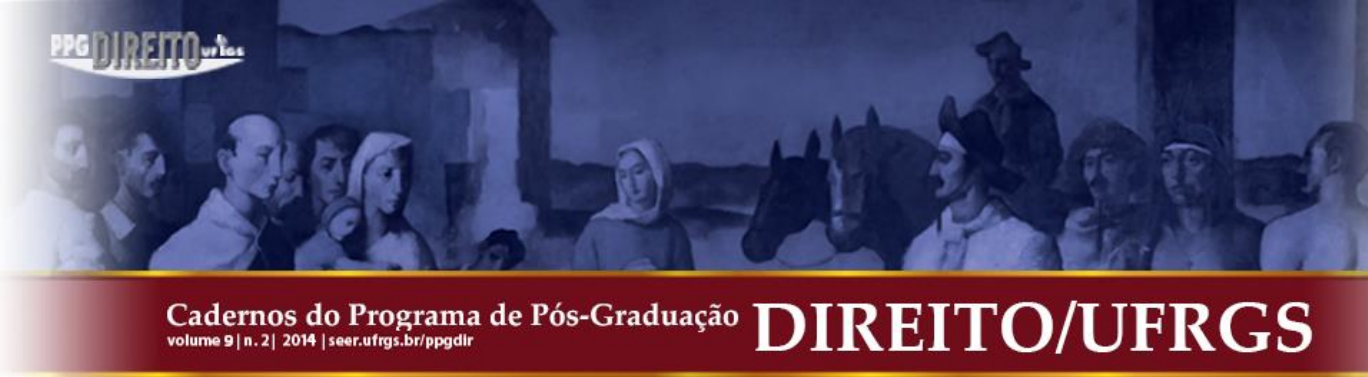

há a atração do Fisco brasileiro, respaldado pelos elementos de conexão de Direito Tributário Internacional.

Considerando que o Estado se sustenta por meio da arrecadação tributária, é legítimo que todos aqueles que sejam residentes fiscais arquem, na medida de sua capacidade contributiva, sem distinção de nacionalidade (aplicação do princípio da isonomia na esfera tributária), com os gastos estatais, que são utilizados em prol da coletividade, para a execução dos serviços públicos, típicos da Administração Pública.

\section{REFERÊNCIAS}

BASSO, Maristela. Curso de direito internacional privado. São Paulo: Atlas, 2009.

BRASIL. Código Tributário Nacional. 16. ed. São Paulo: RT, 2011.

BRASIL. Lei $\mathrm{n}^{\circ}$ 6.815, de 19 de agosto de 1980. Define a situação jurídica do estrangeiro no Brasil, cria o Conselho Nacional de Imigração. Diário Oficial da União, Brasília, 21 ago. 1980.

BRASIL. Lei no 7.064, de 06 de dezembro de 1982. Dispõe sobre a situação de trabalhadores contratados ou transferidos para prestar serviço no exterior. Diário Oficial da União, Brasília, 07 dez. 1982.

BRASIL. Constituição da República Federativa do Brasil. 39. ed. São Paulo: Saraiva, 2012.

BRASIL. Decreto no 3.000, de 26 de março de 1999. Regulamenta a tributação, fiscalização, arrecadação e administração do Imposto sobre a Renda e Proventos de Qualquer Natureza. Diário Oficial da União, Brasília, 17 jun. 1999.

BRASIL. Instrução Normativa n ${ }^{\circ} 208$ da Secretaria da Receita Federal, de 27 de setembro de 2002. Dispõe sobre a tributação, pelo imposto de renda, dos rendimentos recebidos de fontes situadas no exterior e dos ganhos de capital apurados na alienação de bens e direitos situados no exterior por pessoa física residente no Brasil e dos rendimentos recebidos e dos ganhos de 


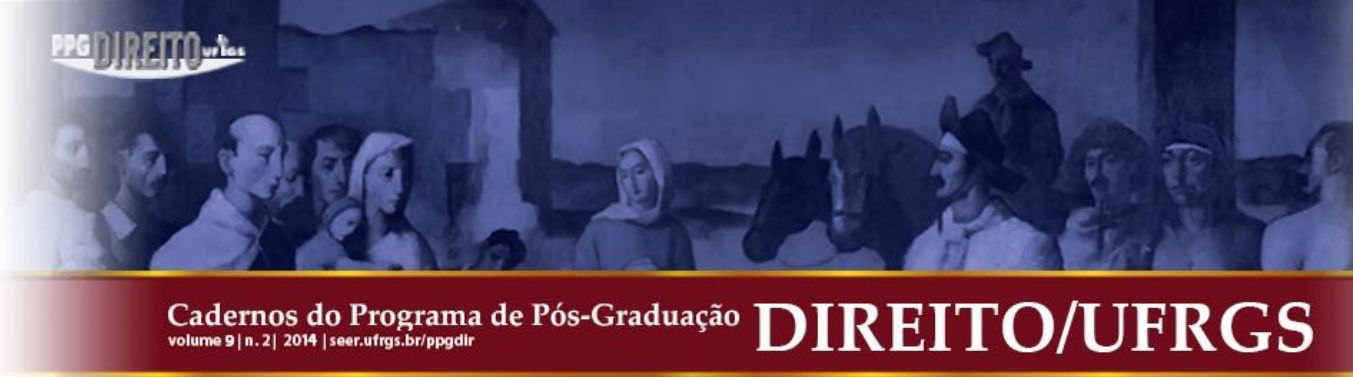

capital apurados no País por pessoa física não residente no Brasil. Diário Oficial da União, Brasília, 01 out. 2002.

BRASIL. Resolução Normativa $n^{\circ}$ 61, de 08 de dezembro de 2004. Disciplina a concessão de autorização de trabalho e de visto a estrangeiro sob contrato de transferência de tecnologia e/ou de prestação de serviço de assistência técnica, de acordo de cooperação ou convênio, sem vínculo empregatício ou em situação de emergência. Diário Oficial da União, Brasília, 23 dez. 2004.

BRASIL. Resolução Normativa $\mathrm{n}^{\circ}$ 95, de 10 de agosto de 2011. Altera dispositivos das Resoluções Normativas $\mathrm{n}^{\mathrm{o}}$ 45, de 14 de março de 2000, e $\mathrm{n}^{\circ}$ 62, de 8 de dezembro de 2004. Diário Oficial da União, Brasília, 19 ago. 2011.

COÊLHO, Sacha Calmon Navarro. Os tratados internacionais em matéria fiscal em face dos acordos comerciais internacionais, regionais, bilaterias ou multilaterais - uma visão jurídica da questão. In: TÔRRES, Heleno Taveira (Coord.). Direito tributário internacional aplicado. v. 2. São Paulo: Quartier Latin, 2004.

GADEX. Grupo de Administração de Expatriados. 2008. Disponível em: <http://www. gadex.com.br/ab_publicacoes.php>. Acesso em: 4 fev. 2012.

KELSEN, Hans. Teoria pura do Direito. 6. ed. Coimbra: Armênio Amado, 1984.

MORAES, Luis Felipe do Nascimento. A transferência internacional de trabalhadores e sua tutela jurídica. Anuário da Faculdade de Direito da Universidade da Coruña, Coruña, n. 13, p. 95-113, 2009. Disponível em: <http://ruc.udc.es/dspace/bitstream/2183/755 3/1/AD_13_art_6.pdf >. Acesso em: 15 set. 2012.

NUNES, Renato. Imposto sobre a Renda Devido por Não Residentes no Brasil: Regime Analítico e Critérios de Conexão. São Paulo: Quartier Latin, 2010.

PONTE, Tatiana da. A equalização fiscal. Você S/A. n. 162. São Paulo, 2011 [on-line]. Disponível em: <http://vocesa.abril.com.br/desenvolva-sua-carreira/materia/artigos-tatianeponte-equalizacao-fiscal-664999.shtml>. Acesso em: 23 ago. 2012.

RAMPI, Nádia de Menezes. Fatores individuais e institucionais no processo de adaptação de profissionais estrangeiros: um estudo na Fundação Dom Cabral. 2009. 117f. Dissertação 


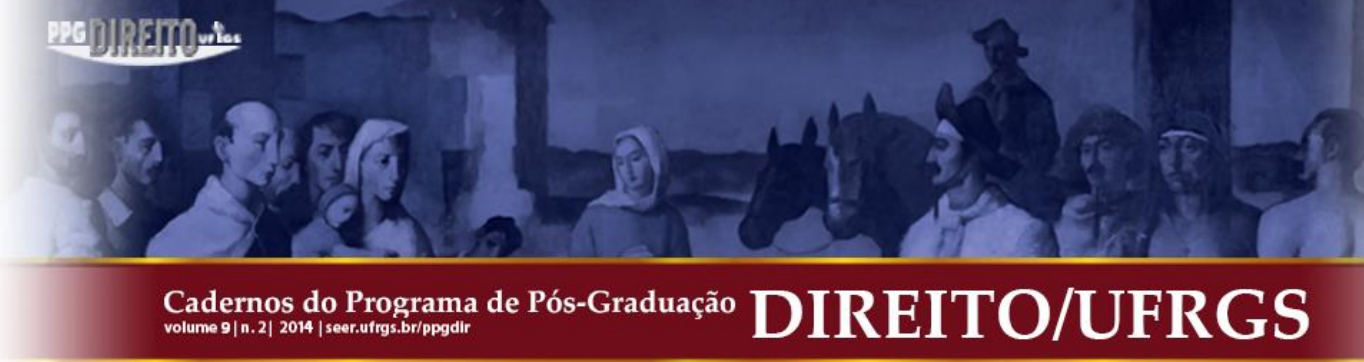

(Mestrado em Administração). Universidade FUMEC, Faculdade de Ciências Empresariais, Belo Horizonte.

SANTIAGO, Igor Mauler. Direito Tributário Internacional: métodos de solução de conflitos. São Paulo: Quartier Latin, 2006.

TÃO perto e tão longe: os expatriados também sentem a crise. 21 set. 2009. Disponível em: $<$ http://www.wharton.universia.net/index.cfm?fa=printArticle \&ID=1791\&language=Portugue se>. Acesso em: 10 set. 2011.

TEIXEIRA, Alessandra Machado Brandão. A residência das pessoas jurídicas no Direito Tributário Brasileiro: art. 75 do Código Civil. In: TÔRRES, Heleno Taveira (Coord.). Direito tributário internacional aplicado - v. 5. São Paulo: Quartier Latin, 2008.

TUNG, R. L. Selecting and training of personnel for overseas assignments. Columbia Journal of World Business, v. 16, n. 2, p. 68-78, 1981.

TÔRRES, Heleno. Pluritributação internacional sobre as rendas de empresas. São Paulo: Revista dos Tribunais, 2001.

XAVIER, Alberto. Direito tributário internacional do Brasil. Rio de Janeiro: Forense, 1995.

Submissão: 13/03/2014

Aceito para Publicação: 20/05/2014 